\title{
PREDIKSI FINANCIAL DISTRESS DENGAN MODEL ALTMAN Z-SCORE MODIFIKASI PADA PERUSAHAAN ASURANSI YANG TERDAFTAR DI BURSA EFEK INDONESIA
}

\author{
I Made Adnyana ${ }^{1}$ \\ Sendy Firdaus ${ }^{2}$ \\ ${ }^{1,2}$ Fakultas Ekonomi dan Bisnis Universitas Nasional \\ Email: madeadnyana085@gmail.com ${ }^{1}$, shendy.firdaus9@gmail.com ${ }^{2}$
}

\begin{abstract}
ABSTRAK
Penelitian ini dilakukan untuk menganalisis potensi terjadinya financial distress dan tingkat klasifikasi Altman Z-score pada perusahaan asuransi yang terdaftar di Bursa Efek Indonesia (BEI). Dengan menggunakan metode purposive sampling, diperoleh sampel sebanyak 9 perusahaan asuransi yang terdaftar di BEI pada periode 2013-2017. Hasil penelitian menunjukkan bahwa terdapat potensi financial distress pada perusahaan asuransi yang terdaftar di BEI. Dalam hal ini, terdapat tiga perusahaan asuransi yang berada dalam grey area.
\end{abstract}

Kata kunci: Financial distress, Altman Z-score, grey area

\begin{abstract}
This research was conducted to analyze the potential of financial distress and Altman Zscore classification level in insurance companies listed on the Indonesia Stock Exchange (IDX). By using purposive sampling method, sample of 9 insurance companies listed on the IDX in the period 2013-2017 is obtained. The results show that there is a potential of financial distress in insurance companies listed on the IDX. In this case, there are three insurance companies that belong in the grey area.
\end{abstract}

Keyword: Financial distress, Altman Z-score, grey area

\section{PENDAHULUAN}

Pertumbuhan perekonomian suatu negara pada dasarnya tidak terlepas dari peranan penting lembaga-lembaga keuangan yang terkait, seperti halnya peranan penting perusahaan asuransi dalam mengurangi risiko di Indonesia. Industri jasa asuransi sendiri merupakan salah satu pilar keuangan yang berguna memproteksi usaha dari segala macam bentuk kecelakaan yang tidak diinginkan. Tanpa asuransi, kemajuan ekonomi yang ada saat ini mustahil dapat tercapai. Data yang dirilis oleh Otoritas Jasa Keuangan (OJK) juga telah membuktikan bahwa industri perasuransian di Indonesia turut berkontribusi dalam memupuk dana jangka panjang dalam jumlah yang besar yang kemudian digunakan sebagai dana dalam pembangunan yang dilakukan oleh pemerintah.

Pada periode 2011-2014 aset industri asuransi konvensional mengalami pertumbuhan rata-rata yang mencapai lebih dari $16 \%$. Pertumbuhan rata-rata yang terjadi 
di dalam nilai investasi dan premi asuransi juga mengalami peningkatan sebesar $14,4 \%$ dan 21,0\% sebagaimana yang diungkapkan oleh Kepala eksekutif Pengawas IKNB, Firdaus Djaelani, dalam seminar Insurance Outlook 2016 di Jakarta. Data tersebut menunjukkan adanya pertumbuhan positif dalam bisnis asuransi. Adapun pada tahun 2015, aset dan investasi industri asuransi konvensional per akhir September bahkan mampu mencapai angka Rp765,6 triliun dan Rp608,6 triliun. Dengan kata lain, terjadi pertumbuhan aset industri asuransi sebesar $1,36 \%$ dan penurunan investasi sebesar $0,24 \%$. Hal tersebut disebabkan oleh adanya gejolak yang terjadi pada beberapa instrumen investasi.

Perusahan yang telah beroperasi dalam jangka waktu tertentu seringkali terpaksa harus berada dalam kondisi kesulitan keuangan (financial distress) karena terus mengalami masalah keuangan di setiap periodenya. Apabila terjadi secara terus menerus, maka financial distress tersebut dapat berakhir pada kebangkrutan. Kondisi financial distress itu sendiri dapat dikenali lebih awal sebelum terjadinya kebangkrutan dengan menggunakan suatu model sistem peringatan dini (early warning system). Model ini dapat digunakan sebagai alat untuk mengenali gejala awal kondisi financial distress untuk selanjutnya dilakukan upaya perbaikan kondisi sebelum sampai pada kondisi krisis atau kebangkrutan.

Dalam rangka memprediksi apakah perusahaan-perusahaan asuransi yang terdaftar di Bursa Efek Indonesia (BEI) dapat tetap bertahan atau mengalami kebangkrutan, dilakukan penelitian dengan menggunakan model Altman Z-score modifikasi. Altman Zscore itu sendiri merupakan model kebangkrutan yang dikembangkan oleh Edward Altman dengan mengkombinasikan lima rasio keuangan yang berbeda-beda untuk menentukan potensi atau kemungkinan bangkrutnya suatu perusahaan. Model revisi terakhir Altman Zscore dipilih karena berdasarkan temuan Anjum (2012) terbukti mempunyai tingkat akurasi sebesar 90,9\% dalam memprediksi kebangkrutan perusahaan satu tahun sebelumnya dan $97 \%$ tingkat akurasi dalam memprediksi tidak bangkrutnya perusahaan melalui pelunasan utang-utangnya.

\section{TINJAUAN PUSTAKA}

\section{Financial Distress}

Financial distress merupakan kondisi dimana keuangan perusahaan dalam keadaan tidak sehat atau kritis dan terjadi sebelum kebangkrutan dan perusahaan mengalami kerugian dalam beberapa tahun (Hapsari, 2012). Menurut Fahmi (2013:158), financial 
distress merupakan tahap penurunan kondisi keuangan yang terjadi sebelum terjadinya kebangkrutan ataupun likuidasi. Financial distress umumnya dimulai dengan ketidakmampuan perusahaan dalam memenuhi kewajiban-kewajibannya, terutama kewajiban yang bersifat jangka pendek, termasuk kewajiban likuiditas dan juga kewajiban dalam kategori solvabilitas.

Menurut Rodoni dan Ali (2014), apabila ditinjau dari kondisi keuangan, ada tiga keadaan yang dapat menyebabkan financial distress, yaitu faktor ketidakcukupan modal atau kekurangan modal, besarnya beban utang dan bunga, serta menderita kerugian. Ketiga aspek tersebut saling berkaitan. Oleh karena itu, ketiganya harus dijaga keseimbangannya agar perusahaan terhindar dari kondisi financial distress yang mengarah kepada kebangkrutan.

\section{Model Altman Z-score}

Pada saat ini, banyak formula yang dikembangkan untuk menjawab permasalahan tentang bankruptcy. Salah satu model yang populer dan banyak dipergunakan dalam berbagai penelitian adalah model kebangkrutan Altman. Model Altman ini lebih umum disebut dengan Altman Z-score (Fahmi, 2013). Menurut Harahap (2010), Altman Z-score dikenal pula sebagai Altman's Bankrupty Prediction Model Z-score. Model ini memberikan rumus untuk menilai kapan perusahaan akan bangkrut. Dengan menggunakan rumus yang diisi dengan rasio keuangan ini, akan diketahui angka tertentu yang dapat digunakan sebagai bahan untuk memprediksi kapan kemungkinan perusahaan akan bangkrut.

Dalam pengembangannya, model Altman Z-score telah mengalami beberapa revisi yang menimbulkan munculnya beberapa model. Model-model tersebut akan dijelaskan lebih lanjut sebagai berikut.

1. Model Altman Pertama

Model ini digunakan untuk memprediksi kebangkrutan pada perusahaan manufaktur yang telah go-public.

$$
Z_{i}=1,2 X_{1}+1,4 X_{2}+3,3 X_{3}+0,6 X_{4}+1,0 X_{5}
$$

(Sumber: Altman, 1968)

Keterangan:

$$
\begin{aligned}
& X_{1}=\text { Working capital to total asset } \\
& X_{2}=\text { Retained earning to total asset } \\
& X_{3}=\text { Earning before interest and tax to total asset }
\end{aligned}
$$




$$
\begin{aligned}
& \mathrm{X}_{4}=\text { Market value of equity to book value of total debt } \\
& \mathrm{X}_{5}=\text { Sales to total asset } \\
& \mathrm{Z}_{\mathrm{i}}=\text { Z-score }
\end{aligned}
$$

Klasifikasi nilai $\mathrm{Z}$ Altman pertama ini dapat dibagi ke dalam tiga kelompok, yaitu sebagai berikut.

a. Nilai $Z<1,8$ mengindikasikan bahwa perusahaan berkemungkinan besar mengalami kebangkrutan.

b. Nilai $\mathrm{Z}$ di antara 1,8 dan $2,99(1,8<\mathrm{Z}<2,99)$ mengindikasikan bahwa perusahaan berada di zona abu-abu (grey area).

c. Nilai $Z>2,99$ mengindikasikan bahwa perusahaan berkemungkinan kecil mengalami kebangkrutan. Dengan kata lain, perusahaan berada dalam kondisi yang sehat.

\section{Model Altman Revisi}

Model ini dikembangkan sehingga tidak hanya dapat digunakan bagi perusahaan manufaktur yang telah go-public, tetapi juga bagi perusahaanperusahaan swasta.

$$
Z_{i}=0,717 X_{1}+0,847 X_{2}+3,107 X_{3}+0,42 X_{4}+0,998 X_{5}
$$

(Sumber: Altman, 1983)

Keterangan:

$$
\begin{aligned}
& \mathrm{X}_{1}=\text { Working capital to total asset } \\
& \mathrm{X}_{2}=\text { Retained earning to total asset } \\
& \mathrm{X}_{3}=\text { Earning before interest and tax to total asset } \\
& \mathrm{X}_{4}=\text { Book value of equity to book value of total debt } \\
& \mathrm{X}_{5}=\text { Sales to total asset } \\
& \mathrm{Z}_{\mathrm{i}}=\text { Z-score }
\end{aligned}
$$

Klasifikasi nilai Z Altman revisi juga dapat dibagi ke dalam tiga kelompok, yaitu sebagai berikut.

a. Nilai $\mathrm{Z}<1,23$ mengindikasikan bahwa perusahaan berkemungkinan besar mengalami kebangkrutan.

b. Nilai $\mathrm{Z}$ di antara 1,23 dan $2,9(1,23<\mathrm{Z}<2,9)$ mengindikasikan bahwa perusahaan berada di zona abu-abu (grey area). 
c. Nilai $Z>2,9$ mengindikasikan bahwa perusahaan berkemungkinan kecil mengalami kebangkrutan. Dengan kata lain, perusahaan berada dalam kondisi yang sehat.

3. Model Altman Modifikasi

Dalam model ini, Altman et al. (1995) mengeliminasi variabel $\mathrm{X}_{5}$, yaitu rasio penjualan terhadap total aset (sales to total asset) karena nilainya sangat bervariasi di berbagai industri.

$$
Z_{i}=6,56 X_{1}+3,26 X_{2}+6,72 X_{3}+1,05 X_{4}
$$

(Sumber: Altman et al.,1995)

Keterangan:

$$
\begin{aligned}
& \mathrm{X}_{1}=\text { Working capital to total asset } \\
& \mathrm{X}_{2}=\text { Retained earning to total asset } \\
& \mathrm{X}_{3}=\text { Earning before interest and tax to total asset } \\
& \mathrm{X}_{4}=\text { Book value of equity to book value of total debt } \\
& \mathrm{Z}_{\mathrm{i}}=\text { Z-score }
\end{aligned}
$$

Klasifikasi nilai Z Altman modifikasi ini dapat dibagi ke dalam tiga kelompok, yaitu sebagai berikut.

a. Nilai $\mathrm{Z}<1,1$ mengindikasikan bahwa perusahaan berkemungkinan besar akan mengalami kebangkrutan.

b. Nilai $\mathrm{Z}$ di antara 1,1 dan $2,6(1,1<\mathrm{Z}<2,6)$ mengindikasikan bahwa perusahaan berada di zona abu-abu (grey area).

c. Nilai $Z>2,6$ mengindikasikan bahwa perusahaan berkemungkinan kecil mengalami kebangkrutan. Dengan kata lain, perusahaan berada dalam kondisi yang sehat.

\section{METODE PENELITIAN}

\section{Sumber dan Jenis Data}

Penelitian ini menggunakan data panel yang berasal dari sumber sekunder, yakni dari laporan keuangan perusahaan-perusahaan yang dijadikan sebagai sampel. 


\section{Populasi dan Sampel}

Populasi dalam penelitian ini adalah perusahaan-perusahaan asuransi yang terdaftar di BEI pada periode 2013-2017, yakni yang seluruhnya terdiri dari 14 perusahaan. Sampel penelitian sebanyak sembilan perusahaan diambil dengan menggunakan metode purposive sampling, yakni dengan kriteria sebagai berikut.

1. Perusahaan menggunakan satuan rupiah dalam laporan keuangannya.

2. Perusahaan memiliki kelengkapan laporan keuangan periode 2013-2017 yang sudah diaudit dan dipublikasikan.

\section{Definisi Operasional dan Pengukuran Variabel}

\section{Z-Score}

Z-score adalah nilai yang menunjukkan kemungkinan suatu perusahaan untuk mengalami kebangkrutan. Dalam penelitian ini, z-score yang digunakan adalah z-score untuk model Altman modifikasi.

\section{Working Capital to Total Asset}

Working capital to total asset adalah rasio yang membandingkan modal kerja dengan total aset perusahaan. Rasio ini digunakan untuk mengukur tingkat likuiditas aktiva perusahaan dan kemampuan perusahaan dalam memenuhi kewajiban jangka pendeknya.

$$
\text { WCTA }=\frac{\text { (Aset lancar }- \text { utang lancar) }}{\text { Jumlah aset }}
$$

(Sumber: Hanafi, 2009)

\section{Retained Earning to Total Asset}

Retained earning to total asset adalah rasio yang membandingkan laba ditahan dengan total aset perusahaan. Variabel ini merupakan pengukuran profitabilitas kumulatif atau laba ditahan perusahaan yang mencerminkan usia perusahaan serta kekuatan pendapatan perusahaan.

$$
\text { RETA }=\frac{\text { Laba ditahan }}{\text { Jumlah aset }}
$$

(Sumber: Hanafi, 2009) 


\section{Earning Before Interest and Tax to Total Asset}

Earning before interest and tax to total asset adalah rasio yang membandingkan laba sebelum bunga dan pajak dengan total aset perusahaan. Rasio ini digunakan untuk mengukur tingkat produktivitas aset perusahaan dalam menghasilkan laba.

$$
\text { EBITTA }=\frac{\text { Pendapatan sebelum pajak }}{\text { Jumlah aset }}
$$

(Sumber: Hanafi, 2009)

\section{Book Value of Equity to Total Liabilities}

Book value of equity to total asset adalah rasio yang membandingkan nilai buku ekuitas dengan total liabilitas perusahaan. Rasio ini menggambarkan besarnya modal perusahaan yang dapat digunakan untuk menanggung beban utang dalam jangka panjang.

$$
\text { BVETL }=\frac{\text { Nilai buku ekuitas }}{\text { Jumlah liabilitas }}
$$

(Sumber: Hanafi, 2009)

\section{Metode Analisis}

Metode analisis yang digunakan dalam penelitian ini adalah model diskriminan Altman Z-score modifikasi karena dinilai lebih akurat mengingat model ini telah mengeliminasi variabel $\mathrm{X}_{5}$, yaitu rasio penjualan terhadap total aset (sales to total asset) karena nilainya sangat bervariasi di berbagai industri.

$$
Z_{i}=6,56 X_{1}+3,26 X_{2}+6,72 X_{3}+1,05 X_{4}
$$

(Sumber: Altman et al., 1995)

Keterangan:

$$
\begin{aligned}
& \mathrm{X}_{1}=\text { Working capital to total asset } \\
& \mathrm{X}_{2}=\text { Retained earning to total asset } \\
& \mathrm{X}_{3}=\text { Earning before interest and tax to total asset } \\
& \mathrm{X}_{4}=\text { Book value of equity to book value of total debt } \\
& \mathrm{Z}_{\mathrm{i}}=\text { Z-score }
\end{aligned}
$$




\section{HASIL DAN PEMBAHASAN}

\section{Analisis Rasio}

1. Working Capital to Total Asset

Tabel 1. Rasio WCTA Perusahaan-Perusahaan Asuransi

di BEI pada Periode 2013-2017

\begin{tabular}{|c|c|c|c|c|c|c|}
\hline No & Kode Perusahaan & $\mathbf{2 0 1 3}$ & $\mathbf{2 0 1 4}$ & $\mathbf{2 0 1 5}$ & $\mathbf{2 0 1 6}$ & $\mathbf{2 0 1 7}$ \\
\hline 1 & ABDA & 0,38 & 0,45 & 0,43 & 0,44 & 0,46 \\
\hline 2 & AHAP & 0,34 & 0,34 & 0,40 & 0,43 & 0,48 \\
\hline 3 & AMAG & 0,45 & 0,50 & 0,43 & $(0,04)$ & $(0,12)$ \\
\hline 4 & ASBI & 0,33 & 0,31 & 0,33 & 0,33 & 0,36 \\
\hline 5 & ASDM & 0,18 & 0,16 & 0,17 & 0,26 & 0,27 \\
\hline 6 & ASMI & 0,35 & 0,39 & 0,40 & 0,44 & 0,53 \\
\hline 7 & ASRM & 0,16 & 0,17 & 0,19 & 0,22 & 0,25 \\
\hline 8 & LPGI & 0,64 & 0,60 & 0,57 & 0,52 & 0,45 \\
\hline 9 & VINS & 0,85 & 0,69 & 0,78 & 0,72 & 0,75 \\
\hline
\end{tabular}

(Sumber: Data diolah, 2019)

Rasio Working Capital to Total Asset (WCTA) perusahaan-perusahaan asuransi di BEI menunjukkan nilai yang beragam selama periode 2013-2017. Hal ini menunjukkan bahwa setiap perusahaan memiliki kemampuan yang berbeda-beda dalam menghasilkan modal kerja bersih dari penggunaan aktiva yang dimilikinya dari tahun ke tahun. Semakin tinggi nilai rasio ini, maka semakin baik kemampuan perusahaan dalam menghasilkan modal kerja bersih, sehingga semakin tinggi tingkat likuiditas aktiva perusahaan tersebut. Sebaliknya, semakin kecil nilai rasio ini, maka semakin rendah kemampuan perusahaan dalam menghasilkan modal kerja bersih, sehingga semakin rendah pula tingkat likuiditas aktiva perusahaan tersebut.

Rasio WCTA tertinggi ada pada PT Victoria Insurance Tbk di periode tahun 2013, yakni dengan nilai sebesar 0,85 yang berarti bahwa setiap pemakaian Rp1 aktiva yang dimilikinya, perusahaan tersebut akan menghasilkan modal kerja bersih sebesar Rp0,85. Adapun rasio WCTA terendah ada pada PT Asuransi Multi Artha Guna Tbk di periode tahun 2017, yakni dengan nilai sebesar -0,12 yang berarti bahwa setiap pemakaian Rp1 aktiva yang dimilikinya, perusahaan tersebut akan menghasilkan modal kerja bersih sebesar -Rp0,12. Modal kerja negatif yang dimaksudkan disini menggambarkan bahwa perusahaan memiliki kewajiban yang lebih banyak daripada asetnya. 


\section{Retained Earning to Total Asset}

Tabel 2. Rasio RETA Perusahaan-Perusahaan Asuransi di BEI pada Periode 2013-2017

\begin{tabular}{|c|c|c|c|c|c|c|}
\hline No & Kode Perusahaan & $\mathbf{2 0 1 3}$ & $\mathbf{2 0 1 4}$ & $\mathbf{2 0 1 5}$ & $\mathbf{2 0 1 6}$ & $\mathbf{2 0 1 7}$ \\
\hline 1 & ABDA & 0,19 & 0,20 & 0,26 & 0,30 & 0,32 \\
\hline 2 & AHAP & 0,25 & 0,26 & 0,21 & 0,24 & 0,15 \\
\hline 3 & AMAG & 0,35 & 0,38 & 0,30 & 0,27 & 0,26 \\
\hline 4 & ASBI & 0,11 & 0,11 & 0,15 & 0,17 & 0,13 \\
\hline 5 & ASDM & 0,14 & 0,13 & 0,14 & 0,22 & 0,24 \\
\hline 6 & ASMI & 0,03 & 0,07 & 0,08 & 0,14 & 0,17 \\
\hline 7 & ASRM & 0,06 & 0,09 & 0,11 & 0,14 & 0,17 \\
\hline 8 & LPGI & 0,20 & 0,20 & 0,22 & 0,24 & 0,26 \\
\hline 9 & VINS & $(0,01)$ & 0,05 & 0,08 & 0,11 & 0,13 \\
\hline
\end{tabular}

(Sumber: Data diolah, 2019)

Rasio Retained Earning to Total Asset (RETA) perusahaan-perusahaan asuransi di BEI menunjukkan nilai yang beragam selama periode 2013-2017. Satu perusahaan bahkan memiliki nilai rasio RETA yang negatif, yaitu PT Victoria Insurance Tbk pada tahun 2013. Hasil rasio ini dapat bernilai minus karena laba ditahan yang dimiliki oleh perusahaan tersebut juga bernilai minus akibat adanya kesalahan kebijakan dalam pembagian dividen, yakni yang ditimbulkan oleh pembagian nilai dividen yang lebih besar kepada pemegang saham daripada nilai laba yang ditahan. Dari seluruh sampel yang diteliti, nilai rasio RETA yang tertinggi dimiliki oleh PT Asuransi Multi Artha Guna Tbk pada tahun 2014, yakni dengan nilai sebesar 0,38 yang berarti bahwa setiap penggunaan aktiva sebesar Rp1 yang dimilikinya, perusahaan tersebut akan menghasilkan laba ditahan dengan nilai sebesar Rp0,38.

\section{Earning Before Interest and Tax to Total Asset}

Tabel 3. Rasio EBITTA Perusahaan-Perusahaan Asuransi di BEI pada Periode 2013-2017

\begin{tabular}{|c|c|c|c|c|c|c|}
\hline No & Kode Perusahaan & $\mathbf{2 0 1 3}$ & $\mathbf{2 0 1 4}$ & $\mathbf{2 0 1 5}$ & $\mathbf{2 0 1 6}$ & $\mathbf{2 0 1 7}$ \\
\hline 1 & ABDA & 0,41 & 0,44 & 0,48 & 0,47 & 0,42 \\
\hline 2 & AHAP & 0,07 & 0,06 & 0,02 & 0,02 & $(0,10)$ \\
\hline 3 & AMAG & 0,34 & 0,35 & 0,29 & 0,22 & 0,20 \\
\hline 4 & ASBI & 0,04 & 0,03 & 0,06 & 0,02 & 0,02 \\
\hline 5 & ASDM & 0,15 & 0,14 & 0,14 & 0,18 & 0,19 \\
\hline 6 & ASMI & 0,01 & 0,03 & 0,01 & 0,07 & 0,06 \\
\hline 7 & ASRM & 0,03 & 0,05 & 0,05 & 0,05 & 0,05 \\
\hline 8 & LPGI & 0,06 & 0,06 & 0,04 & 0,43 & 0,47 \\
\hline 9 & VINS & 0,07 & 0,12 & 0,16 & 0,04 & 0,04 \\
\hline
\end{tabular}

(Sumber: Data diolah, 2019) 
Rasio Earning Before Interest and Tax to Total Asset (EBITTA) perusahaanperusahaan asuransi di BEI menunjukkan nilai yang beragam selama periode 2013-2017. Satu perusahaan bahkan memiliki nilai rasio EBITTA yang negatif, yaitu PT Asuransi Harta Aman Pratama Tbk pada tahun 2017. Hasil rasio ini dapat bernilai minus karena jumlah beban yang harus dibayar oleh perusahaan asuransi tersebut lebih besar daripada jumlah pendapatan yang diterima. Adapun nilai rasio EBITTA yang terbesar dimiliki oleh PT Asuransi Bina Dana Arta Tbk di tahun 2015, yakni dengan nilai sebesar 0,48. Artinya, setiap penggunaan Rp1 aktiva yang dimilikinya, perusahaan tersebut akan menghasilkan nilai laba sebelum pajak sebesar Rp0,48. Hal ini menunjukkan bahwa semakin tinggi nilai rasio EBITTA, maka semakin baik kinerja suatu perusahaan dalam mengelola hartanya untuk menghasilkan laba sebelum pajak.

\section{Book Value of Equity to Total Liabilities}

Tabel 4. Rasio BVETL Perusahaan-Perusahaan Asuransi di BEI pada Periode 2013-2017

\begin{tabular}{|c|c|c|c|c|c|c|}
\hline No & Kode Perusahaan & $\mathbf{2 0 1 3}$ & $\mathbf{2 0 1 4}$ & $\mathbf{2 0 1 5}$ & $\mathbf{2 0 1 6}$ & $\mathbf{2 0 1 7}$ \\
\hline 1 & ABDA & 0,61 & 0,83 & 0,75 & 0,78 & 0,86 \\
\hline 2 & AHAP & 0,51 & 0,51 & 0,66 & 0,77 & 0,91 \\
\hline 3 & AMAG & 1,40 & 1,68 & 1,35 & 1,05 & 0,91 \\
\hline 4 & ASBI & 0,48 & 0,46 & 0,48 & 0,49 & 0,57 \\
\hline 5 & ASDM & 0,22 & 0,19 & 0,20 & 0,34 & 0,38 \\
\hline 6 & ASMI & 0,54 & 0,64 & 0,67 & 0,77 & 1,13 \\
\hline 7 & ASRM & 0,19 & 0,20 & 0,24 & 0,28 & 0,34 \\
\hline 8 & LPGI & 1,74 & 1,53 & 1,34 & 1,06 & 0,83 \\
\hline 9 & VINS & 5,63 & 2,22 & 3,58 & 2,51 & 2,98 \\
\hline
\end{tabular}

(Sumber: Data diolah, 2019)

Rasio Book Value of Equity to Total Liabilities (BVETL) perusahaan-perusahaan asuransi di BEI menunjukkan nilai yang beragam selama periode 2013-2017. Rasio BVETL terendah dimiliki oleh PT Asuransi Ramayana Tbk pada tahun 2013, yakni dengan nilai sebesar 0,19. Adapun rasio BVETL tertinggi dimiliki oleh PT Victoria Insurance Tbk pada tahun 2013, yakni dengan nilai sebesar 5,63 yang berarti bahwa setiap Rp1 total kewajiban yang dimiliki oleh perusahaan tersebut dicakup oleh sebesar Rp5,63 nilai buku ekuitas yang dimilikinya. Dengan demikian, semakin tinggi nilai rasio ini, maka semakin tinggi pula kemampuan perusahaan dalam memenuhi seluruh kewajibannya dengan nilai buku ekuitas yang dimilikinya. 


\section{Analisis Z-Score}

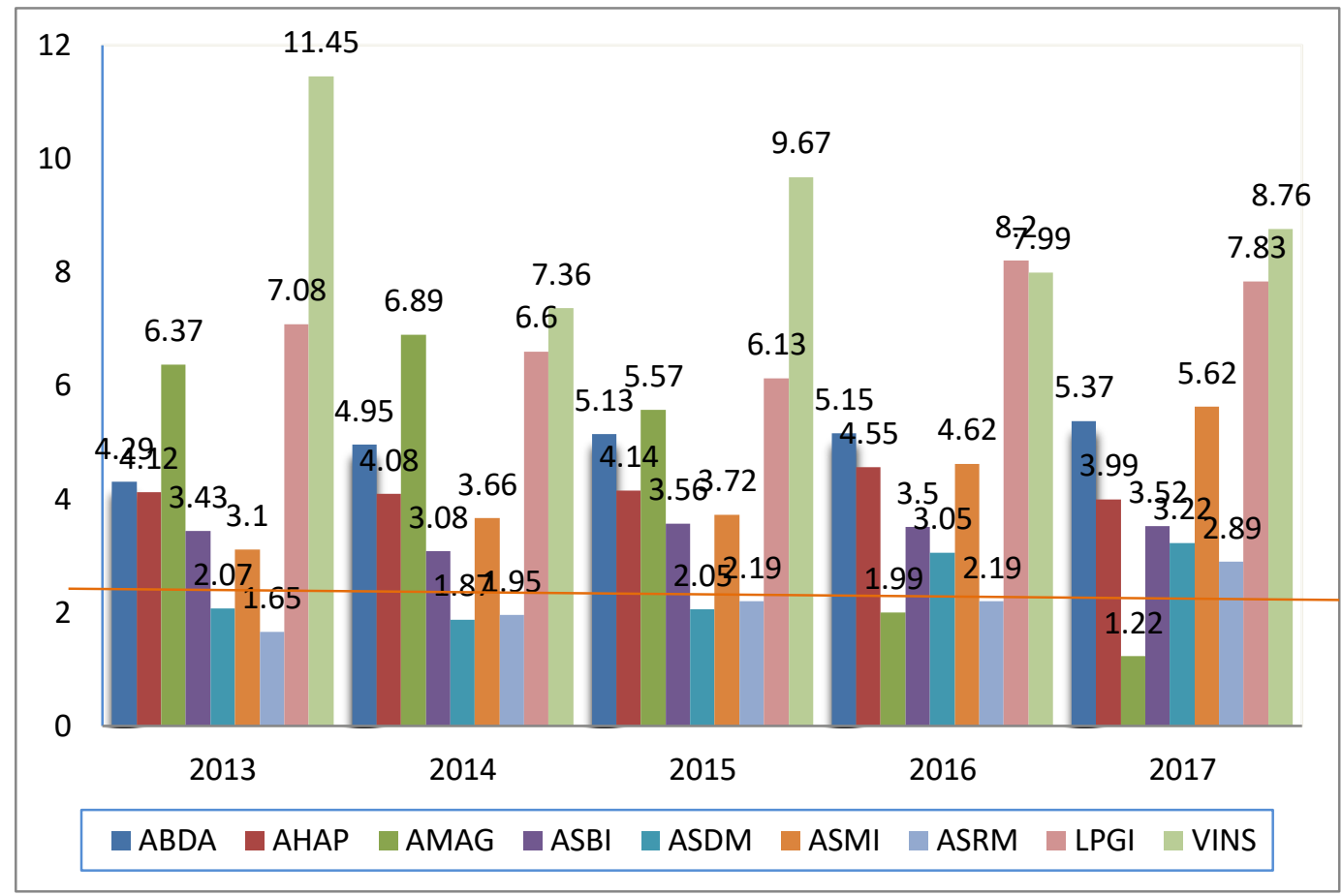

(Sumber: Data diolah, 2019)

\section{Gambar 1. Grafik Pergerakan Z-Score Perusahaan-Perusahaan Asuransi di BEI pada Periode 2013-2017}

Hasil cut-off z-score pada perusahaan-perusahaan asuransi di BEI terlihat mengalami fluktuasi dan bahkan cenderung mengalami tren yang menurun. Pada tahun 2013, terdapat tujuh perusahaan asuransi yang berada dalam kondisi keuangan sehat, sementara dua perusahaan asuransi lainnya berada dalam kategori grey area. Perusahaan dengan cut-off z-score tertinggi pada tahun 2013 sehingga dapat dikatakan sebagai perusahaan asuransi yang paling sehat adalah PT Victoria Insurance Tbk, yakni dengan nilai sebesar 11,45. Adapun perusahaan dengan cut-off z-score terendah pada tahun tersebut adalah PT Asuransi Ramayana Tbk, yakni dengan nilai sebear 1,65.

Pada tahun 2014, terdapat tujuh perusahaan asuransi yang berada dalam kondisi keuangan sehat, sementara dua perusahaan asuransi lainnya berada dalam kategori grey area. Perusahaan dengan cut-off z-score tertinggi pada tahun 2014 sehingga dapat dikatakan sebagai perusahaan asuransi yang paling sehat adalah PT Victoria Insurance Tbk, yakni dengan nilai sebesar 7,36. Adapun perusahaan dengan cut-off z-score terendah pada tahun tersebut adalah PT Asuransi Dayin Mitra Tbk, yakni dengan nilai sebesar 1,87. 
Pada tahun 2015, terdapat tujuh perusahaan asuransi yang berada dalam kondisi keuangan sehat, sementara dua perusahaan asuransi lainnya berada dalam kategori grey area. Perusahaan dengan cut-off $z$-score tertinggi pada tahun 2015 sehingga dapat dikatakan sebagai perusahaan asuransi yang paling sehat adalah PT Victoria Insurance Tbk, yakni dengan nilai sebesar 9,67. Adapun perusahaan dengan cut-off z-score terendah pada tahun tersebut adalah PT Asuransi Dayin Mitra Tbk, yakni dengan nilai sebesar 2,09.

Pada tahun 2016 terdapat tujuh perusahaan asuransi yang berada dalam kondisi keuangan sehat, sementara dua perusahaan asuransi lainnya berada dalam kategori grey area. Perusahaan dengan cut-off z-score tertinggi pada tahun 2016 sehingga dapat dikatakan sebagai perusahaan asuransi yang paling sehat adalah PT Lippo General Insurance Tbk, yakni dengan nilai sebesar 8,2. Adapun perusahaan dengan cut-off z-score terendah pada tahun tersebut adalah PT Asuransi Multi Artha Guna Tbk, yakni dengan nilai sebesar 1,99 .

Pada tahun 2017, jumlah perusahaan asuransi yang berada dalam kondisi keuangan sehat naik menjadi delapan perusahaan, sehingga hanya satu perusahaan yang berada dalam kategori grey area. Perusahaan dengan cut-off z-score tertinggi pada tahun 2017 sehingga dapat dikatakan sebagai perusahaan asuransi yang paling sehat adalah PT Victoria Insurance Tbk, yakni dengan nilai sebesar 8,76. Adapun perusahaan dengan cutoff z-score terendah pada tahun tersebut adalah PT Asuransi Multi Artha Guna Tbk, yakni dengan nilai sebesar 1,22.

\section{KESIMPULAN DAN SARAN}

\section{Kesimpulan}

Berdasarkan hasil analisis yang telah dilakukan, dapat ditarik kesimpulan sebagai berikut.

1. Pada tahun 2013-2016, terdapat tujuh perusahaan asuransi yang dikategorikan berada dalam kondisi yang sehat, sementara dua perusahaan asuransi lainnya dikategorikan berada dalam grey area.

2. Pada tahun 2017, jumlah perusahaan asuransi yang berada dalam kondisi yang sehat mengalami kenaikan, yakni menjadi delapan perusahaan, sehingga hanya satu perusahaan asuransi yang berada dalam kategori grey area.

3. Pada tahun 2013-2017, tidak terdapat perusahaan asuransi yang masuk dalam klasifikasi perusahaan bangkrut berdasarkan nilai cut-off z-score. 


\section{Saran}

Berdasarkan kesimpulan di atas, saran yang dapat direkomendasikan adalah sebagai berikut.

1. Perusahaan yang diklasifikasikan masuk ke dalam perusahaan yang sehat diharapkan dapat mempertahankan kondisinya tersebut dengan senantiasa memperhatikan segala aspek yang mempengaruhi kesehatan perusahaan dan melakukan berbagai upaya pencegahan agar tidak mengalami kebangkrutan.

2. Perusahaan yang diklasifikasikan masuk ke dalam grey area diharapkan dapat meningkatkan kinerjanya agar pada waktu berikutnya tidak mengalami penurunan yang dapat mengakibatkan terjadinya kebangkrutan. Pihak manajemen perusahaan dalam kategori ini juga diharapkan dapat lebih memperhatikan asetnya, sehingga tidak terjadi over investment dan perusahaan dapat lebih produktif dalam menghasilkan laba. Arus modal kerja yang dihasilkan juga harus dijaga agar bernilai positif, sehingga terhindar dari dampak buruk terhadap kinerja. Selain itu, perusahaan juga perlu memperhatikan biaya utangnya agar tidak semakin meningkat, sehingga tidak menimbulkan kenaikan risiko yang tidak diinginkan.

\section{DAFTAR PUSTAKA}

Altman, E.I. 1968. Financial Ratios, Discriminant Analysis and the Prediction of Bankruptcy. The Journal of Finance. 23(4): 589-609.

1983. Corporate Financial Distress: A Complete Guide to Predicting, Avoiding and Dealing with Bankruptcy. Wiley and Sons. New York.

, Y.H. Eom. dan D.W. Kim. 1995. Failure Prediction: Evidence from Korea. Journal of International Financial Management and Accounting. 6(3): 230-249.

Anjum, S. 2012. Business Bankruptcy Prediction Models: A Significant Study of the Altman's Z-Score Model. Asian Journal of Management Research. 3(1): 212-219.

Annuri, I.F.A. dan Ruzikna. 2017. Analisis Penggunaan Metode Altman (Z-Score) dalam Memprediksi Terjadinya Financial Distress pada Perusahaan Minyak Bumi dan Gas (Migas) yang Terdaftar di Bursa Efek Indonesia Periode 2010-2014. Jom FISIP. 4(2).

Fahmi, I. 2013. Analisis Laporan Keuangan. Alfabeta. Bandung.

Hanafi, M.M. 2009. Manajemen Keuangan. BPFE. Yogyakarta.

Hapsari, E.I. 2012. Kekuatan Rasio Keuangan dalam Memprediksi Kondisi Financial Distress. Jurnal Dinamika Manajemen. 3(2): 101-109. 
Harahap, S.S. 2010. Analisis Kritis atas Laporan Keuangan. Rajagrafindo Persada. Jakarta.

Ikatan Akuntan Indonesia. 2009. Standar Akuntansi Indonesia. Salemba Empat. Jakarta.

Kasmir. 2014. Analisis Laporan Keuangan. Rajagrafindo Persada. Jakarta.

Munawir. 2016. Analisa Laporan Keuangan. Liberty. Yogyakarta.

Rodoni, A. dan H. Ali. 2014. Manajemen Keuangan Modern. Mitra Wacana Media. Jakarta.

Sucipto. 2003. Penilaian Kinerja Keuangan. Jurnal Akuntansi USU. 